\title{
Commentary
}

\section{Issues, Impacts, and Mitigations of Carbon Dioxide Emissions in the Building Sector}

\author{
Khozema Ahmed Ali, Mardiana Idayu Ahmad *(i) and Yusri Yusup *(i) \\ Environmental Technology Division, School of Industrial Technology, Universiti Sains Malaysia, \\ Penang 11800, Malaysia; khozema@usm.my \\ * Correspondence: mardianaidayu@usm.my (M.I.A.); yusriy@usm.my (Y.Y.)
}

Received: 12 August 2020; Accepted: 31 August 2020; Published: 10 September 2020

\begin{abstract}
Climate change has become a considerable concern for humanity during this anthropocentric era. Scientists believe that the rate of global warming and climate change varies directly with the increase in the concentration of greenhouse gases, particularly carbon dioxide. Urbanization is happening at a higher rate in this era than in any other generation. It was reported that the building sector plays a critical role in the emission of carbon dioxide $\left(\mathrm{CO}_{2}\right)$ into the atmosphere. Construction of buildings, operation, and utilization of the built environment has led to emissions of a large number of $\mathrm{CO}_{2}$ into the ambient air. Various issues and challenges arise from the building sector in reducing $\mathrm{CO}_{2}$ emissions. The exploitation of non-renewable energy resources, poor building design, and lack of sustainability consideration in urbanization has been holding back $\mathrm{CO}_{2}$ emission mitigation measures in the building sector. Therefore, $\mathrm{CO}_{2}$ emission mitigation plans and schemes are necessary alongside standardized frameworks and guidelines. The strategies to reduce $\mathrm{CO}_{2}$ in the building sector are enforcing standards and policy, conducting impact assessment, adopting low carbon technology, and restricting energy utilization. All stakeholders must play their roles efficiently to reduce $\mathrm{CO}_{2}$ emissions and aid in the fight against climate change.
\end{abstract}

Keywords: $\mathrm{CO}_{2}$ emissions; building sector; impacts; mitigations

\section{Introduction}

The increasing average atmospheric temperature has led to global warming, which drives a set of changes to the Earth's climate and weather systems. These swift changes are happening as humans continue to emit heat-trapping greenhouse gases (GHG) to the atmosphere [1]. Among these emissions, carbon dioxide $\left(\mathrm{CO}_{2}\right)$ is the critical anthropogenic greenhouse gas due to its abundance and its ability to remain in the atmosphere for thousands of years [2].

$\mathrm{CO}_{2}$ emissions can be from natural and human sources. One of these sources originates from the urbanization process. Urbanization is a dynamic process that changes rural areas into urban areas with an increasing number of people and the expansion of the built environment horizontally and vertically. The built environment is the anthropogenic surroundings that provide infrastructure and facilities for human activities, and they are the fundamental components of the economy and social development of a nation. Thus, the acceleration of urbanization played a considerable role in rising $\mathrm{CO}_{2}$ emissions in the building sector.

In general, the building sector ranges from construction to operation, which can be further divided into residential and non-residential buildings. These include the processes of adding structures to areas of land and the operation, service, and maintenance of the building. With the building sector facing a resurgence in growth, a massive direct and indirect impact on the environment has been reported. It is considered as one of the significantly consuming and waste generating sectors of the economy [3]. The environmental impact of this sector can be categorized into ecosystem impacts, natural resource 
impacts, and public impacts [4]. This sector is also responsible for significant energy consumption and emission production, such as GHG emissions, particulate matter, sulfur dioxide, carbon monoxide, and nitrogen oxide [5]. As a result of the energy consumption from this sector, the ambient $\mathrm{CO}_{2}$ level has increased, which generates enormous proportions of $\mathrm{CO}_{2}$ emissions [6,7]. Sources of $\mathrm{CO}_{2}$ emissions in this sector can be from the energy utilization required for the manufacturing and transportation of the building materials to the processing of resources, construction waste disposal, and the demands of construction equipment [8].

The building sector consumes a substantial portion of non-renewable energy and prompts the emission of a significant amount of $\mathrm{CO}_{2}$ [9]. Building contributes approximately $39 \%$ of the annual global $\mathrm{CO}_{2}$ [10] (Figure 1). It has been reported that more than a third of the usage of total energy and $\mathrm{CO}_{2}$ emissions is a result of the building sector in the developed and developing nations [11]. Therefore, $\mathrm{CO}_{2}$ emission mitigation measures are crucial [12]. To promote $\mathrm{CO}_{2}$ emission mitigation, planning on conservation of energy, and implementation of strategies to reduce potential emission mitigation should be prioritized [13]. This paper aims to provide an overview of the issues, impacts, and mitigation strategies in the building sector to reduce and control $\mathrm{CO}_{2}$ emissions.

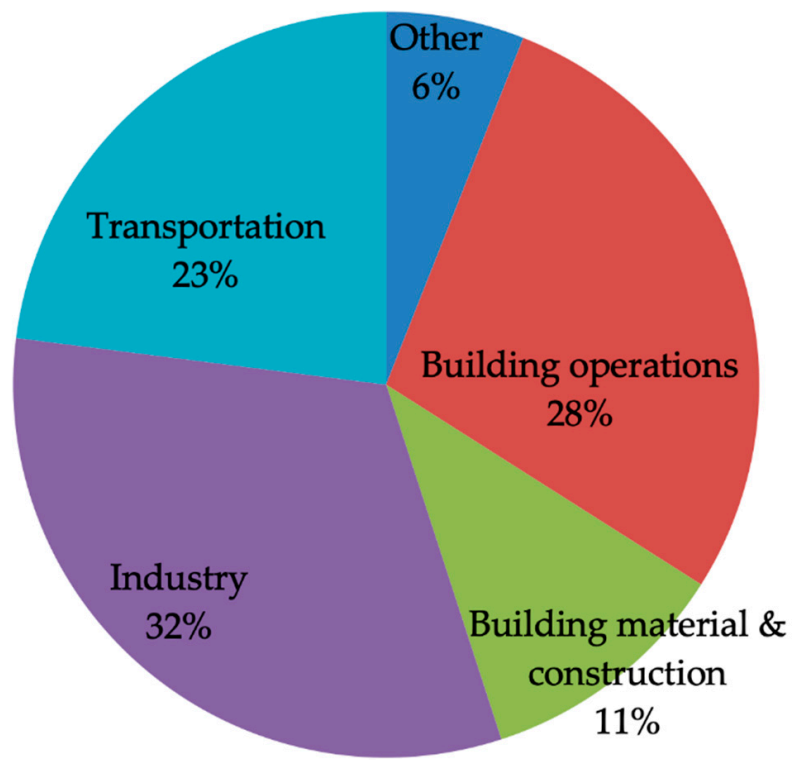

Figure 1. Global $\mathrm{CO}_{2}$ emission by sectors.

\section{Issues and Challenges}

The challenge in sustainably advancing the building sector is the increasingly large outflows of $\mathrm{CO}_{2}$ due to the utilization of non-sustainable energy sources in the planning, construction, and operations of buildings [9]. $\mathrm{CO}_{2}$ is also emitted from the broad utilization of land in the urbanization process [11]. The energy sourced from fossil fuels is non-sustainable, and yet it accounts for a large percentage of the energy used in the construction and operation processes. Sustainable or renewable energy sources only account for $6 \%$ of the total energy used in the sector, while fossil fuel used in construction activities accounts for $40 \%$ of worldwide greenhouse gas emissions. Although numerous novel methods have been proposed to lessen the $\mathrm{CO}_{2}$ footprint of buildings, particularly in high-density urban communities, the challenge has yet to be solved appreciably [14].

The utilization of a non-sustainable energy source directly affects the environment, and it is directly proportional to the amount used. The construction of a building emits $\mathrm{CO}_{2}$, both directly and indirectly. Direct $\mathrm{CO}_{2}$ emissions originate from the burning of natural gas, diesel, light fuel oil, and other oil-based commodities, while indirect $\mathrm{CO}_{2}$ emissions come from the application of electricity. Globally, the indirect $\mathrm{CO}_{2}$ emission accounts for $85 \%$ of the total $\mathrm{CO}_{2}$ emitted, while only $14 \%$ is from direct emissions. 
The 2030 Climate and Energy Framework states that 27\% of energy should be sourced from sustainable energy sources, while energy efficiency or productivity should increase by $27 \%$ [15]. However, there are challenges in finding sustainable solutions to low productivity and efficiency. One solution is to itemize the processes of construction and operation so that detailed evaluations can be carried out. Construction includes the assembly of the building material, the development of the structure and foundation, and the transportation and operation of machinery. The procedure comprises the maintenance aspect of the building and its infrastructure. The evaluation of the life cycle requires a detailed inventory of these processes in all phases of the building's life. The assessment would highlight strategies that could be made more productive and efficient.

\section{Impacts and Consequences}

It is well-known that $\mathrm{CO}_{2}$ emissions contribute to global warming and climate change, which can significantly cause severe impacts and consequences for humans and the environment. $\mathrm{CO}_{2}$ emissions act like a blanket in the air, trapping heat in the atmosphere, and warming up the Earth [11]. This layer prevents the Earth from cooling, and thus raises global temperatures.

Global warming would affect environmental conditions, food and water supplies, weather pattern, and sea levels. Based on the National Oceanic and Atmospheric Administration (NOAA) Global Climate Summary, it stated that combined land and ocean temperature since 1880 has increased with an average rate of $0.07^{\circ} \mathrm{C}$ per decade. The temperature continues rising since 1981, with an average rate of $0.18^{\circ} \mathrm{C}$, which is over twice as massive as previous times.

Figure 2 illustrates the impact of $\mathrm{CO}_{2}$ emissions as a result of rising global temperatures. The release of $\mathrm{CO}_{2}$ alters water supplies and changes harvesting seasons. For instance, climate change undermines coastal and marine regions with rising ocean levels, which triggers a rising demand for food crops. $\mathrm{CO}_{2}$ also causes acid rain, which physically damages trees [16] and the built environment $[17,18]$. These impacts and consequences of $\mathrm{CO}_{2}$ emissions can be seen now. They extend well beyond the rising global temperatures, which is affecting ecological systems and communities across the world.

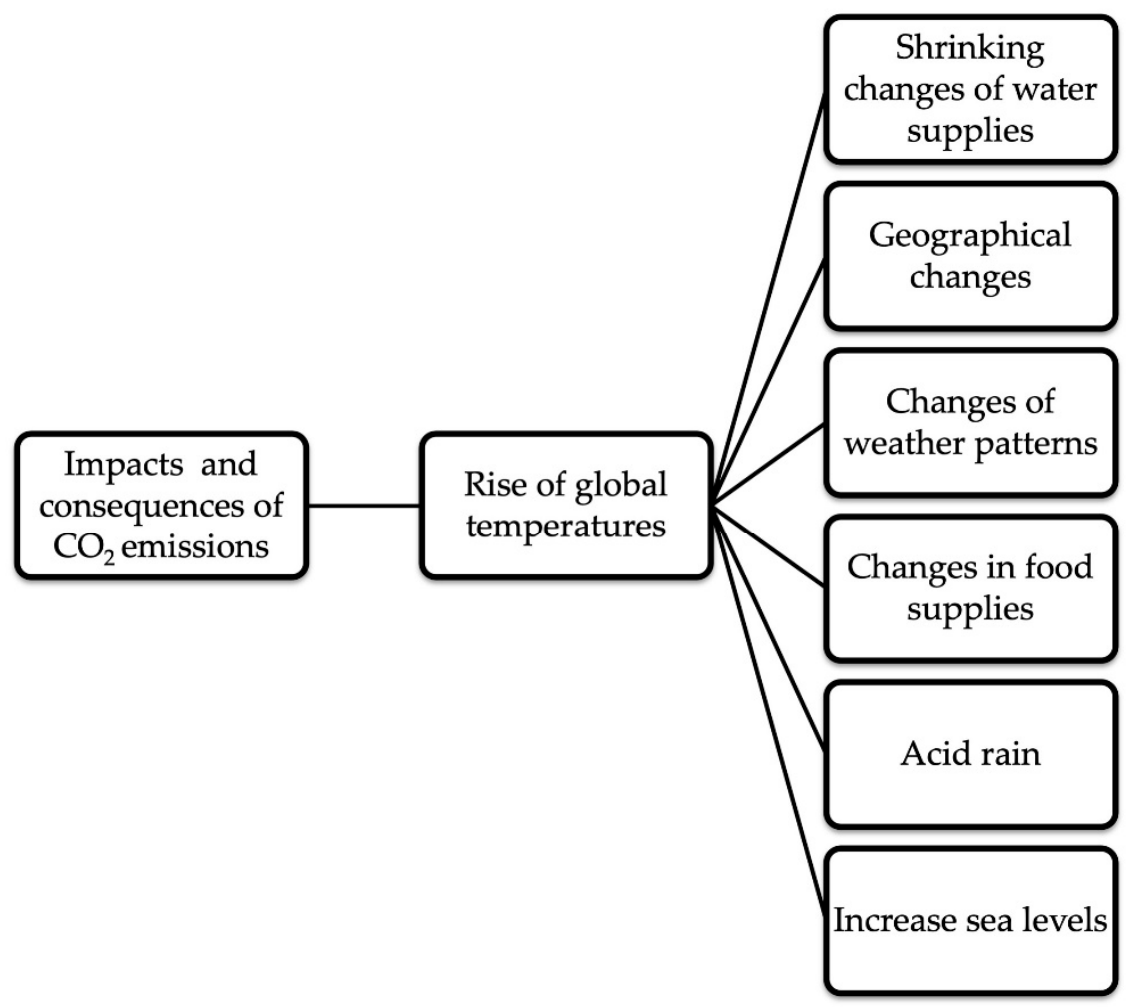

Figure 2. Impacts and consequences of $\mathrm{CO}_{2}$ emissions on the environment. 


\section{Strategies and Way Forward}

Over the past two decades, governments and policymakers have been urged to take action to mitigate $\mathrm{CO}_{2}$ emissions in various sectors [12]. This section discusses several strategies to reduce $\mathrm{CO}_{2}$ emissions in response to concerns on the global warming challenge in the building sector (Figure 3). These strategies can be applied at various scales towards $\mathrm{CO}_{2}$ emissions reduction.

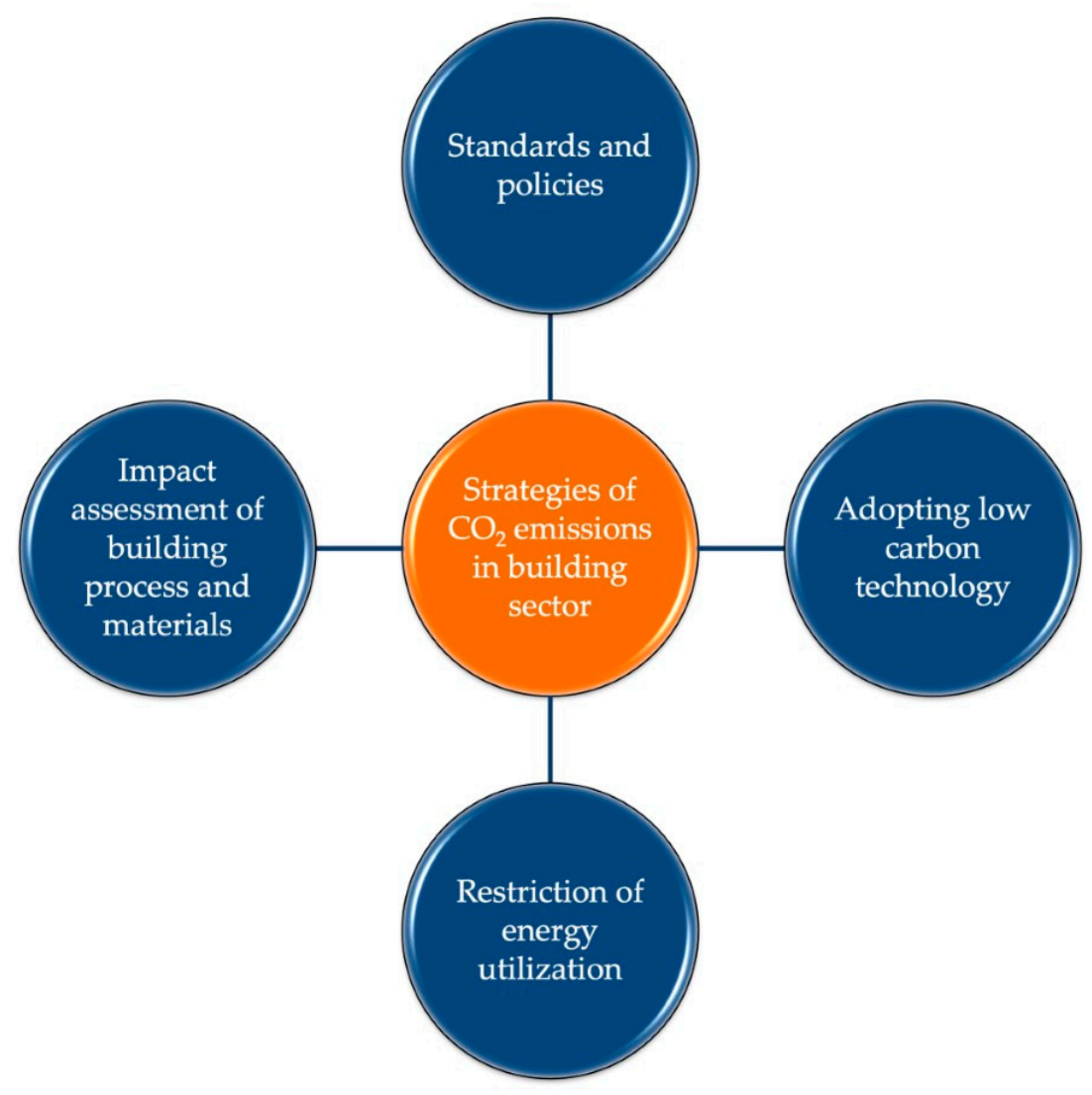

Figure 3. Strategies in reducing $\mathrm{CO}_{2}$ emissions in the building sector.

\subsection{Standards and Policy}

Many sustainable building standards, codes, policies, and guidelines packages have been introduced in many countries across the world, which aim to improve building energy performance and reduce $\mathrm{CO}_{2}$ emissions. Under the Paris Agreement commitment and the United Nations Sustainable Development Goals, Nationally Determined Contribution (NDC) was set up in 2015 for the decarbonization of the building sector. A total of 184 countries participated in the NDC. Governments have taken initiatives in the decarbonization of the building sector through the establishment of policies and standards. Table 1 summarizes existing standards and policies committed by selected countries under this strategy, that incorporate the reduction of $\mathrm{CO}_{2}$ emissions in their goals and objectives. These packages set minimum requirements for energy performance and efficiency in buildings towards zero or low carbon buildings. There are more than 60 countries worldwide that initiated plans to implement these either mandatorily or voluntarily $[19,20]$. 
Table 1. Existing standards associated with the reduction of $\mathrm{CO}_{2}$ emissions in buildings as part of prioritizing action on the Nationally Determined Contribution (NDC), which was set up in 2015 under the Paris Agreement commitment and the United Nations Sustainable Development Goals.

\begin{tabular}{cl}
\hline Country & \multicolumn{1}{c}{ Standards or Policies } \\
\hline \multirow{3}{*}{ China } & $\begin{array}{l}\text { The Energy Consumption of Buildings standard was introduced by the Ministry of } \\
\text { Housing and Urban-Rural Development in 2016. This standard covers indicators of energy } \\
\text { use for various building types. It aims to limit the amount of building sector energy } \\
\text { consumption of the country and simultaneously limit the total } \mathrm{CO}_{2} \text { emissions. }\end{array}$ \\
\hline \multirow{3}{*}{ Australia } & $\begin{array}{l}\text { The Australian Federal Government launched the National Carbon Offset Standard for } \\
\text { Buildings in 2017. It was established in collaboration with the Green Building Council } \\
\text { Australia. The main objective of the standard is to provide to measure, reduce, offset, } \\
\end{array}$ \\
& report, and audit $\mathrm{CO}_{2}$ emissions from building operations.
\end{tabular}
A policy was introduced in 2016 as part of the Energy Conservation Act of 2001, which is aimed at commercial buildings under the Perform, Achieve, and Trade (PAT) program. It had saved about 9 million tons of oil equivalent (Mtoe) of final energy, thereby reducing

India annual $\mathrm{CO}_{2}$ emissions by nearly $23 \mathrm{MtCO}_{2}$. The Energy Conservation Building Code (ECBC) was updated in 2017 for commercial buildings that recognized improvement efforts towards decarbonization. In 2018, the first national model building energy code called the Energy Conservation Building Code for Residential Buildings was introduced with simple enforcement of thermal comfort and passive system improvement.

As part of the Clean Energy for all European policy package set in 2016, the European Commission targets to combat climate change contributed by GHGs, including $\mathrm{CO}_{2}$

European Union emissions, through proposals on energy efficiency, energy market, and renewable energy strategies. An amendment to the Energy Performance of Buildings Directive (EPBD) was published in 2018 to achieve high-energy efficiency and be decarbonized by 2050 .

In 2016, the Centre for Sustainable Construction was created under a Swedish Government

Sweden policy to promote the usage of sustainable materials and energy-efficient renovations, which could also reduce $\mathrm{CO}_{2}$ emissions. In 2019, a certification scheme addressing the environmental impact of a new building was introduced.

\begin{tabular}{cl}
\hline \multirow{3}{*}{ Japan } & In 2017, the act on the Improvement of Energy Consumption Performance of Buildings \\
(Building Energy Efficiency Act) was introduced, which includes regulatory measures for \\
mandatory compliance with energy efficiency standards for non-residential buildings. \\
This act is part of the Japanese government policy on the zero-energy-building \\
[ZEB]/zero-energy-house [ZEH] system to be achieved by 2030.
\end{tabular}


In China, the National Development and Reform Commission (NDRC) has introduced the Emission Trading Scheme (ETS) to support $\mathrm{CO}_{2}$ emission mitigation. For the building sector, the Ministry of Housing and Urban-Rural Development (MOHURD) has advised the Green Building Action Plan to encourage energy-saving systems on municipal buildings, shopping malls, workplaces, etc. [21]. In 2008, the "Guidelines to Account for and Report on Greenhouse Gas Emissions and Removals for Buildings," were published in Hong Kong, targeted to help to build owners to evaluate their GHG emission level. Since 2015, the companies, which are listed in the Stock Exchange of Hong Kong (SEHK), are obligated to reveal the annual environmental and social information according to the Companies Ordinance. Explicitly, environmental subjects cover emissions, consumptions, and environmental impacts [22]. The Building Energy Efficiency Ordinance (BEEO) was legislated in 2012, involving owners of commercial buildings to conduct an energy audit based on the Energy Audit Code for their central building services installation every ten years.

In Japan, large building holders were encouraged to implement energy-saving practices and environmentally friendly designs via the Green Building Program launched by the Tokyo Metropolitan in 2002 [21]. While for offices, commercial, standard and industrial buildings, there was a Tokyo Cap-and-Trade Program of Japan presented in 2010, targeted to reduce energy consumption. In America, the concern of $\mathrm{CO}_{2}$ emission has led to the implementation of policies by the local, state, and federal governments. One of the programs implemented by the U.S. Green Building Council (USGBC) is the Leadership in Energy and Environmental Design (LEED) certification [23]. The LEED certification offers many advantages in building construction and technologies practices, such as water efficiency and materials and resources [24]. Many of the U.S federal government bodies use LEED certification as the building benchmark. According to USGBC, more than 273 regulatory policies have been enacted by the city, county, and state level to encourage LEED certification of the commercial building [25]. In 2006, a memorandum of understanding (MOU) was made in the USA that provided a voluntary guideline for high-performing and sustainable buildings. Based on that, Executive order 13,423 (2007) required all construction of new federal buildings to comply with the MOU. Fund amounting to $\$ 31$ billion was granted to green building and conservation under the Energy Policy Act of 2009. Most of the state and local green building policies mandate LEED certification for a specific sector. For example, government buildings in 23 countries, 30 counties, and 170 cities are required to meet the LEED certification requirement. Sixty cities, including Connecticut, require significant commercial buildings to obtain at least silver LEED certification. Policies, including incentives and symbolic gestures, are summarized by Matisoff and Noonan [24].

\subsection{Adopting Low Carbon Technology}

Low carbon technology is one of the technical strategies that can be adopted in buildings to reduce carbon dioxide emissions. Low carbon technology refers to the technology that has a minimal output of GHG emissions into the environment, specifically for $\mathrm{CO}_{2}$ emissions [26]. Examples of renewable and sustainable energy technologies are evaporative cooling, passive ventilation and cooling, solar photovoltaic, dehumidification, and energy recovery systems. These technologies have been proven to significantly help to decrease emissions and promote energy savings in buildings. Through low carbon technology, the development of basic strategy requirements of innovation-driven development in the building can also be achieved [27]. However, the downside of the low carbon technology implementation is it might increase the operation cost of buildings. Therefore, systematic consideration should be addressed carefully to ensure the balance between the reduction of $\mathrm{CO}_{2}$ emissions and investment of the technology.

\subsection{Restriction Strategy}

Closing down the operation in particular areas and shutting down associated devices is a straightforward approach to minimizing the $\mathrm{CO}_{2}$ emissions and energy utilization in buildings. The most accessible practice is to keep the doors closed and switching off the lights and electrical 
appliances of vacant rooms. It is defined as the restriction strategy when this is practiced in public buildings. Most of the public buildings, such as teaching blocks, libraries, and fitness centers, have been grouped into several sections according to the usage rate. In these public buildings, restriction strategy is achievable if unused areas are closed, and users have to gather in certain permitted areas to share the services. Hence, energy consumption is reduced. A study reported the linkage between building occupant rate and energy consumption in their study [28]. A significant decline in lighting and heating energy consumption per capita with the increase of occupant rate has been displayed.

Nevertheless, when the occupant rate increases, it might lead to the dissatisfaction of occupants. In general, high occupant rates usually reduce air quality, ultimately affecting the operational effectiveness of the occupants. Therefore, the major obstacle of the restriction strategy is energy conservation refuting the occupants' satisfaction.

\subsection{Impact Assessment of Building Process and Materials}

Understanding the entire building process is very important in mitigating $\mathrm{CO}_{2}$ emissions. These processes include extraction, manufacturing, transportation, construction, maintenance, and disposal. Wide ranges of material are utilized in buildings that use energy and release $\mathrm{CO}_{2}$ through its life cycle, which is regarded as embodied energy and embodied carbon. As part of mitigation measures, assessment of embodied carbon of building materials is one of the fundamental approaches that can have a positive impact on carbon footprint. The selection of appropriate sustainable building materials can reduce about $30 \%$ of embodied $\mathrm{CO}_{2}$ emissions over a lifespan of the building $[29,30]$. Through this assessment, it has been reported that reinforced concrete and clay bricks are the most carbon-emitting materials leading to approximately $60 \%$ to $70 \%$ of the total embodied carbon $[31,32]$. Detailed inventories on building materials and embodied carbon are presented in Hammond and Jones [33,34]. Besides, to reduce $\mathrm{CO}_{2}$ emissions or meet the emissions targets, sustainable or low carbon materials can be considered in the manufacturing process. Low carbon cement, timber, straw, and compressed Earth, which has lower carbon footprints are some excellent alternatives.

Therefore, it is necessary to discover the primary building materials that have an apparent influence on the environment and include them in the sustainability assessment scope. This discovery could simplify the evaluation method and attain quick environmental impact assessment. Analysis of $\mathrm{CO}_{2}$ emissions, weight, cost, and energy consumption of building materials is shown in Table 2 [35]. The $\left(\mathrm{kg} \mathrm{CO}_{2} \mathrm{e} / \mathrm{m}^{2}\right)$ is a functional unit used for the carbon emission of building material in the embodied stage. This functional unit provides a benchmark value so that the carbon emission values for buildings of different sizes are consistent and could be compared [36]. The calculation for $\mathrm{CO}_{2}$ emissions was conducted by the quota method using this formula (Equation (1)):

$$
Q C_{M g}=\sum_{i=1}^{n} C M_{r i} \times m_{i}
$$

where,

$Q C_{M g}$ is the $\mathrm{CO}_{2}$ emission equivalent released in the building material production process.

$C M_{r i}$ is the carbon emission factor in the production process of the building material without considering recycling.

$m_{i}$ is the amount of building material.

As for energy consumption, the formula (Equation (2)) used to calculate the value is:

$$
Q E_{M e}=\sum_{i=1}^{n} E M_{r i} \times m_{i}
$$

where,

$Q E_{M e}$ is the energy consumption for the building material in the production process. 
$E M_{r i}$ is the energy factor of the building material during the production process without considering recycling.

Finally, the cost of the building material in the embodied stage is calculated using this formula (Equation (3)):

$$
\mathrm{QTC}_{M c}=\sum_{i=1}^{n} U C M_{r i} \times m_{i}
$$

where,

$Q T C_{M c}$ is the total cost of building material in the embodied stage.

$U C M_{r i}$ is the unit cost of a building material without considering recycling.

The carbon emission factors, the energy factors, and the unit cost of the building materials are reported in the previous studies [37-40]. From this study, mortar, commercial concrete, wall materials, steel and doors, and windows contribute to about $80 \%$ of carbon emission. Thus, $\mathrm{CO}_{2}$ emissions of buildings should be identified and analyzed from the necessary structural forms. Hence mortar, commercial concrete, wall materials, and steel should be given more attention when implementing $\mathrm{CO}_{2}$ emission mitigation measures.

Table 2. $\mathrm{CO}_{2}$ emissions, weight, cost, and the energy consumption of building materials [35].

\begin{tabular}{|c|c|c|c|c|}
\hline Materials & $\begin{array}{c}\mathrm{CO}_{2} \text { Emissions } \\
\left(\mathrm{kgCO}_{2} \mathrm{e} / \mathrm{m}^{2}\right)\end{array}$ & $\begin{array}{l}\text { Weight } \\
\left(\mathrm{kg} / \mathrm{m}^{2}\right)\end{array}$ & $\begin{array}{c}\text { Cost }\left(\mathrm{RMB} / \mathrm{m}^{2} ;\right. \\
\left.\mathrm{USD} / \mathrm{m}^{2} ; \mathrm{EUR} / \mathrm{m}^{2}\right)\end{array}$ & $\begin{array}{c}\text { Energy Consumption } \\
\left(\mathrm{MJ} / \mathrm{m}^{2}\right)\end{array}$ \\
\hline Steel & 142.23 & 64.86 & $279.54 ; 40.72 ; 34.20$ & 1415.80 \\
\hline Commercial concrete & 123.94 & 905.3 & $440.06 ; 64.10 ; 53.84$ & 209.37 \\
\hline Wall materials & 68.19 & 334.13 & $37.88 ; 5.52 ; 4.63$ & 260.29 \\
\hline Mortar & 58.1 & 372.76 & $29.61 ; 4.31 ; 3.62$ & 223.69 \\
\hline PVC pipes & 33.44 & 5.89 & $7.56 ; 1.10 ; 0.92$ & 16.96 \\
\hline Polystyrene extrusion board & 21.25 & 1.08 & $15.06 ; 2.19 ; 1.84$ & 15.81 \\
\hline Architectural ceramics & 12.12 & 3.13 & $3.19 ; 0.46 ; 0.39$ & 22.91 \\
\hline Doors and windows & 9.54 & 5.41 & $70.5 ; 10.27 ; 8.63$ & 112.12 \\
\hline Water paints & 5.03 & 0.68 & $7.76 ; 1.13 ; 0.95$ & 19.82 \\
\hline Copper core conductor cables & 2.58 & 0.27 & $14.07 ; 2.05 ; 1.72$ & 12.21 \\
\hline Wood & 1.40 & 5.03 & $6.61 ; 0.96 ; 0.81$ & 5.88 \\
\hline Waterproof roll & 0.62 & 0.51 & $4.25 ; 0.62 ; 0.52$ & 0.02 \\
\hline Stone & 0.47 & 17.12 & $5.43 ; 0.79 ; 0.66$ & 3.63 \\
\hline Total & 478.91 & 1716.16 & $921.51 ; 134.23 ; 112.75$ & 2318.50 \\
\hline
\end{tabular}

In mitigating $\mathrm{CO}_{2}$, proposed solutions should also combine sustainable energy sources, such as solar and wind energy and biofuels, in the operations of buildings through life cycle assessment. The building sector has great potential to lessen $\mathrm{CO}_{2}$ emissions during its operational stage by using less energy at the planning, building, and operation steps by increasing efficiency and enhancing construction standards. The goal of the life cycle assessment is to reduce environmental effects and costs. With this regard, a global assessment methodology was developed in 2011 called EN 15978:2011, which provides the calculation steps and analysis rules for the environmental performance assessment of new and existing buildings [41]. This strategy can incorporate all periods of the building's life cycle. For example, Hong Kong has analyzed the life cycle of buildings under its jurisdiction. Their focus is to decrease energy usage by $25 \%$ from the 2005 level by 2030 [14]. The life cycle assessment can distinguish the life cycles of the structure from the operation of the building [15]. The operation and embedded carbon footprint of the building is considered in the construction and maintenance of the building. The construction process includes $\mathrm{CO}_{2}$ emissions from the creation, development, maintenance, and substitution of building materials and services of the building [15]. The energy used in maintenance corresponds to the operation carbon footprint for a given fuel blend. Steps used in limiting the operation carbon footprint can adversely affect the embedded carbon footprint.

On the other hand, aside from new buildings, impact assessment of historical or old buildings should also be considered, which can be an appropriate solution to reduce $\mathrm{CO}_{2}$ emissions. As reported 
in the literature, on average, buildings have an exceptionally long lifespan between 60 to 120 years. Based on this lifespan, historical or old buildings are still in use, and it is expected that $80 \%$ of existing buildings will continue to be occupied in 2050 [42]. Understanding of principles, materials, methods, risks, and technologies is essential towards decarbonization in these buildings by analyzing their building materials and elements. A detailed life cycle assessment can be carried out by taking into account several factors towards $\mathrm{CO}_{2}$ mitigations such as operational energy performance, reuse, and sustainable refurbishment, retrofitting solutions, building envelope thermal performance improvements, heating, cooling, ventilation and lighting systems, and adaptation of passive measures $[43,44]$.

\section{Conclusions}

The building sector plays a significant part in the emissions of $\mathrm{CO}_{2}$ globally. The tremendous production and release of $\mathrm{CO}_{2}$ have led to severe consequences and repercussions contributing to climate change. The adverse effects of the non-sustainable built environment have not only put a strain on the environment but also have affected humanity. This paper provided an overview of the issues, impacts, and mitigation strategies in the building sector to reduce and control $\mathrm{CO}_{2}$ emissions. The energy sourced from fossil fuels is non-sustainable, and yet it accounts for a large percentage of the energy used in the construction and operation processes. The strategies to reduce $\mathrm{CO}_{2}$ in the building sector are enforcing standards and policy, conducting impact assessment, adopting low carbon technology, and restricting energy utilization. If we continue with the current approach for the building sector, it will be too late to rectify the mistakes of our predecessors. The future of sustainable cities and communities will remain uncertain, and we might fail to achieve global sustainable development goals. The building sector must be given enough attention and care to reduce the rate of $\mathrm{CO}_{2}$ emissions. A comprehensive and thorough analysis is necessary to study the $\mathrm{CO}_{2}$ emission mitigation measures in the building sector, and global organizations must come up with a holistic framework to tackle the issue. For a more sustainable future, it is crucial to implement drastic actions and measures to reduce $\mathrm{CO}_{2}$ emissions to aid the fight in combating climate change.

Author Contributions: Conceptualization, M.I.A., K.A.A. and Y.Y.; investigation, K.A.A., and M.I.A.; methodology, Y.Y. and K.A.A.; project administration, M.I.A., Y.Y., K.A.A.; resources, K.A.A. and Y.Y.; visualization, M.I.A., Y.Y. and K.A.A.; writing-original draft, M.I.A., Y.Y. and K.A.A.; writing-review and editing, M.I.A., Y.Y. and K.A.A.; project administration, Y.Y. and M.I.A.; funding acquisition, M.I.A. All authors have read and agreed to the published version of the manuscript.

Funding: This work was supported by Research University Grant [1001/PTEKIND/8014124] from Universiti Sains Malaysia.

Conflicts of Interest: The authors declare no conflict of interest. The funders had no role in the design of the study; in the collection, analyses, or interpretation of data; in the writing of the manuscript, or in the decision to publish the results.

\section{References}

1. Alhorr, Y.; Eliskandarani, E.; Elsarrag, E. Approaches to reducing carbon dioxide emissions in the built environment: Low carbon cities. Int. J. Sustain. Built Environ. 2014, 3, 167-178. [CrossRef]

2. Riffat Sb, M.A. Building Energy Consumption and Carbon dioxide Emissions: Threat to Climate Change. J. Earth Sci. Clim. Chang. 2015, S3. [CrossRef]

3. Bilal, M.; Khan, K.I.A.; Thaheem, M.J.; Nasir, A.R. Current state and barriers to the circular economy in the building sector: Towards a mitigation framework. J. Clean. Prod. 2020, 276, 123250. [CrossRef]

4. Zolfagharian, S.; Nourbakhsh, M.; Irizarry, J.; Ressang, A.; Gheisari, M. Environmental Impacts Assessment on Construction Sites. In Construction Research Congress 2012; American Society of Civil Engineers: West Lafayette, IN, USA, 2012; pp. 1750-1759.

5. Sandanayake, M.; Zhang, G.; Setunge, S. Estimation of environmental emissions and impacts of building construction-A decision making tool for contractors. J. Build. Eng. 2019, 21, 173-185. [CrossRef] 
6. Adams, S.; Nsiah, C. Reducing carbon dioxide emissions; Does renewable energy matter? Sci. Total Environ. 2019, 693, 133288. [CrossRef]

7. Chang, C.-T.; Yang, C.-H.; Lin, T.-P. Carbon dioxide emissions evaluations and mitigations in the building and traffic sectors in Taichung metropolitan area, Taiwan. J. Clean. Prod. 2019, 230, 1241-1255. [CrossRef]

8. Yan, H.; Shen, Q.; Fan, L.C.; Wang, Y.; Zhang, L. Greenhouse gas emissions in building construction: A case study of One Peking in Hong Kong. Build. Environ. 2010, 45, 949-955. [CrossRef]

9. Huang, L.; Krigsvoll, G.; Johansen, F.; Liu, Y.; Zhang, X. Carbon emission of global construction sector. Renew. Sustain. Energy Rev. 2018, 81, 1906-1916. [CrossRef]

10. IEA. World Energy Statistics and Balances (Database). 2019. Available online: www.iea.org/statistics (accessed on 12 August 2020).

11. Klufallah, M.M.; Nuruddin, M.F.; Khamidi, M.F.; Jamaludin, N. Assessment of Carbon Emission Reduction for Buildings Projects in Malaysia-A Comparative Analysis. In E3S Web of Conferences; EDP Sciences: Bangi, Malaysia, 2014; Volume 3.

12. Langevin, J.; Harris, C.B.; Reyna, J.L. Assessing the Potential to Reduce U.S. Building $\mathrm{CO}_{2}$ Emissions $80 \%$ by 2050. Joule 2019, 3, 2403-2424. [CrossRef]

13. Ma, M.; Ma, X.; Cai, W.; Cai, W. Carbon-dioxide mitigation in the residential building sector: A household scale-based assessment. Energy Convers. Manag. 2019, 198, 111915. [CrossRef]

14. Yim, S.; Ng, S.T.; Hossain, U.; Wong, J.M.W. Comprehensive Evaluation of Carbon Emissions for the Development of High-Rise Residential Building. Buildings 2018, 8, 147. [CrossRef]

15. Pal, S.K.; Takano, A.; Alanne, K.; Siren, K. A life cycle approach to optimizing carbon footprint and costs of a residential building. Build. Environ. 2017, 123, 146-162. [CrossRef]

16. Paoletti, E.; Manes, F. Effects of elevated carbon dioxide and acidic rain on the growth of holm oak. In Developments in Environmental Science; Elsevier: Amsterdam, The Netherlands, 2003; pp. 375-389.

17. Cellura, M.; Guarino, F.; Longo, S.; Tumminia, G. Climate change and the building sector: Modelling and energy implications to an office building in southern Europe. Energy Sustain. Dev. 2018, 45, 46-65. [CrossRef]

18. Bravo, A.H.; Soto, A.R.; Sosa, E.R.; Sánchez, A.P.; Alarcón, J.A.L.; Kahl, J.; Ruíz, B.J. Effect of acid rain on building material of the El Tajin archaeological zone in Veracruz, Mexico. Environ. Pollut. 2006, 144, 655-660. [CrossRef]

19. Abergel, T.; Dean, B.; Dulac, J. Towards a Zero-Emission, Efficient, and Resilient Buildings and Construction Sector: Global Status Report 2017; UN Environment and International Energy Agency: Paris, France, 2017.

20. UN Environment and International Energy Agency. Towards a zero-emissions, efficient and resilient buildings and construction sector. In 2019 Global Status Report for Buildings and Construction; UN Environment and International Energy Agency: Paris, France, 2019.

21. Lu, M.; Lai, J. Review on carbon emissions of commercial buildings. Renew. Sustain. Energy Rev. 2020, 119, 109545. [CrossRef]

22. Legislative Council of the Hong Kong Special Administrative Region. 2020. Available online: https://www.legco.gov.hk/index.html (accessed on 12 August 2020).

23. Adekanye, O.G.; Davis, A.; Azevedo, I.L. Federal policy, local policy, and green building certifications in the U.S. Energy Build. 2020, 209, 109700. [CrossRef]

24. Matisoff, D.C.; Noonan, D.S.; Flowers, M.E. Policy Monitor-Green Buildings: Economics and Policies. Rev. Environ. Econ. Policy 2016, 10, 329-346. [CrossRef]

25. U.S. Green Building Council. Public Policy Library. Available online: https://public-policies.usgbc.org/ (accessed on 12 August 2020).

26. Tan, Y.C.; Ismail, M.; Ahmad, M.I. Turbine Ventilator as Low Carbon Technology. In Renewable Energy and Sustainable Technologies for Building and Environmental Applications; Ahmad, M., Ismail, M., Riffat, S., Eds.; Springer: Cham, Switzerland, 2016.

27. IPCC. Summary for Policymakers. In Climate Change 2007: The Physical Science Basis. Contribution of Working Group I to the Fourth Assessment Report of the Intergovernmental Panel on Climate Change; Solomon, S., Qin, D., Manning, M., Chen, Z., Marquis, M., Averyt, K.B., Tignor, M., Miller, H.L., Eds.; Cambridge University Press: Cambridge, UK; New York, NY, USA, 2007.

28. Chen, Y.; Liu, H.; Shi, L. Operation strategy of public building: Implications from trade-off between carbon emission and occupant satisfaction. J. Clean. Prod. 2018, 205, 629-644. [CrossRef] 
29. González, M.J.; Navarro, J.G. Assessment of the decrease of $\mathrm{CO}_{2}$ emissions in the construction field through the selection of materials: Practical case study of three houses of low environmental impact. Build. Environ. 2006, 41, 902-909. [CrossRef]

30. Chastas, P.; Theodosiou, T.; Kontoleon, K.J.; Bikas, D. Normalising and assessing carbon emissions in the building sector: A review on the embodied $\mathrm{CO}_{2}$ emissions of residential buildings. Build. Environ. 2018, 130, 212-226. [CrossRef]

31. Kumanayake, R.; Luo, H.; Paulusz, N. Assessment of material related embodied carbon of an office building in Sri Lanka. Energy Build. 2018, 166, 250-257. [CrossRef]

32. Robati, M.; Daly, D.; Kokogiannakis, G. A method of uncertainty analysis for whole-life embodied carbon emissions $\left(\mathrm{CO}_{2}\right.$-e) of building materials of a net-zero energy building in Australia. J. Clean. Prod. 2019, 225, 541-553. [CrossRef]

33. Hammond, G.; Jones, C. Inventory of Carbon and Energy; United Overseas Bank Ltd.: London, UK, 2008.

34. Hammond, G.; Jones, C. Embodied Carbon: The Inventory of Carbon and Energy (ICE); Lowrie, F., Tse, P., Eds.; BSRIA: Bracknell, Berkshire, UK, 2011.

35. Cang, Y.; Yang, L.; Luo, Z.; Zhang, N. Prediction of embodied carbon emissions from residential buildings with different structural forms. Sustain. Cities Soc. 2020, 54, 101946. [CrossRef]

36. Luo, Z.; Yang, L.; Liu, J. Carbon Dioxide Emissions of Office Buildings at Embodied Stage. J. Civ. Archit. Environ. Eng. 2014, 37-43. [CrossRef]

37. Luo, Z.; Yang, L.; Liu, J.; Han, B. Research on $\mathrm{CO}_{2}$ Emission Calculation Method and $\mathrm{CO}_{2}$ Reduction Strategies of Building Materials. Build. Sci. 2011, 27, 1-8.

38. Xin, C. $\mathrm{CO}_{2}$ Emission Assesment of Office Building Equipment Pipeline; Cheng Kung University: Taiwan, 2008.

39. Zhixing, L. Study on Calculation Method of Building Life Cycle $\mathrm{CO}_{2}$ Emission and Emission Reduction Strategies; Xi'an University of Architecture and Technology: Xi'an, China, 2011.

40. Jiangsu Provincial Department Of Construction. Proce Table of Architecture and Decoration Engineering in Jiangsu Province; next and last volume; Jiangsu Provincial Department Of Construction: Jiangsu, China, 2004.

41. BS. EN15978 Sustainability of Construction Works: Assessment of Environmental Performance of Buildings: Calculation Method; British Standards Institution: London, UK, 2011.

42. Loron, M.S.; Ismail, S.; Yunos, M.Y.B.M. Energy Efficiency for Reducing Carbon Footprint in Historic Buildings: Comparing Case in the UK and Malaysia. Adv. Environ. Biol. 2015, 9, 82-84.

43. Sesana, E.; Bertolin, C.; Gagnon, A.S.; Hughes, J. Mitigating Climate Change in the Cultural Built Heritage Sector. Climate 2019, 7, 90. [CrossRef]

44. Berg, F.; Fuglseth, M. Life cycle assessment and historic buildings: Energy-efficiency refurbishment versus new construction in Norway. J. Archit. Conserv. 2018, 24, 152-167. [CrossRef] 